\title{
Aplikasi Kirim Pesan Berbasis Jaringan Lokal Dengan Menerapkan Algoritma RSA Sebagai Teknik Dalam Menjaga Kerahasiaan Pesan
}

\author{
Dony Catur Dermawan ${ }^{1)}$, Triawan Adi Cahyanto ${ }^{2)}$ \\ ${ }^{1,2)}$ Jurusan Teknik Informatika, Fakultas Teknik, Universitas Muhammadiyah Jember \\ Email: ${ }^{1)}$ donycad2212@ gmail.com, ${ }^{2)}$ triawanac@unmuhjember.ac.id
}

\begin{abstract}
Abstrak : Aplikasi kirim pesan bermanfaat untuk berkomunikasi dengan pengguna di area yang terbatas dengan koneksi internet. Permasalahan muncul ketika penggunaan aplikasi kirim pesan yang berjalan di jaringan lokal akan rentan terhadap serangan Man In The Middle seperti sniffing. Algoritma RSA merupakan salah satu algoritma kriptografi yang bersifat asimetris, yakni mempunyai kunci publik dan kunci pribadi. Penggunaan dua kunci ini merupakan teknik untuk menjaga kerahasiaan pesan yang berjalan di aplikasi kirim pesan. Pengujian tingkat keamanan terhadap aplikasi kirim pesan dilakukan dengan teknik sniffing. Hasil pengujian keamanan aplikasi, diperoleh data ciphertext dari proses enkripsi plaintext dengan algoritma RSA, namun kunci publik yang digunakan untuk melakukan enkripsi tidak berhasil dipecahkan sehingga tidak dapat melihat pesan yang dikirimkan pada aplikasi tersebut.
\end{abstract}

\section{Kata kunci : Kriptografi, Local Area Network, RSA, Chatting}

\section{PENDAHULUAN}

Pertukaran pesan (chatting) merupakan layanan murah, cepat dan inovatif dalam rangka berbagi informasi antar pengguna di suatu tempat. Banyak aplikasi kirim pesan seperti WhatsApp, Telegram, BBM dan lain-lain yang memberikan kemudahan dalam berinteraksi, bahkan tidak hanya bertukar pesan namun juga bertukar suara dan video. Namun, mayoritas aplikasi kirim pesan tersebut membutuhkan koneksi internet untuk saling terhubung antar pengguna (Cahyanto, 2018). Untuk area yang tidak terjangkau akses internet, tentunya akan menyebabkan aplikasi tersebut menjadi tidak berguna (Cahyanto, Oktavianto, \& Royan, 2013). Aplikasi kirim pesan berbasis jaringan lokal dibuat dengan tujuan sebagai layanan alternatif kirim pesan di area yang sulit terhadap akses internet. Aplikasi ini berjalan di jaringan lokal seperti kantor, kampus, kafe, dan tempat lainnya. Penggunaan aplikasi di jaringan tentunya akan menimbulkan dampak terhadap aplikasi tersebut, terutama dari sisi keamanan proses pengiriman pesan (Cahyanto \& Prayudi, 2014). Oleh karena itu, supaya pesan yang dikirimkan dapat terjaga kerahasiaannya, maka perlu dikembangkan aplikasi pesan dengan algoritma RSA sebagai mekanisme keamanan dalam pengiriman data. Algoritma RSA merupakan algoritma kriptografi yang bersifat asimetrik (Munir, 2010). Asimetrik yang dimaksud adalah terdapat dua kunci, yaitu kunci publik dan kunci pribadi. Kunci publik digunakan dalam proses enkripsi pesan dan kunci publik ini umumnya dapat diketahui oleh publik beserta dengan data ciphertext, sedangkan kunci pribadi digunakan dalam membuka ciphertext (pesan yang terenkripsi) namun kunci ini hanya dimiliki oleh si pengirim dan penerima pesan (Xin Zhou, Xiaofei Tang, Zhou, \& Tang,
2011). Penggunaan faktorisasi bilangan prima sebagai proses pembentukan kunci dengan mode sistem block cipher membuat algoritma RSA sulit untuk dipecahkan dalam waktu yang singkat (Vikas, Agrawal, \& Deshmukh, 2014).

\section{TINJAUAN PUSTAKA}

\subsection{Jaringan Komputer}

Jaringan komputer adalah kumpulan perangkat yang saling terhubung dalam satu kesatuan yang bekerja bersama-sama agar tercapai tujuan yang diharapkan (Cahyanto, 2011). Berdasarkan ruang lingkupnya, jaringan komputer dibagi menjadi tiga jenis, yaitu :

1. Local Area Network (LAN)

Merupakan jaringan yang mempunyai ruang lingkup terbatas di suatu area tertentu, seperti kantor, kampus, pabrik, dan lain sebagainya.

2. Metropolitan Area Network (MAN)

Merupakan jaringan yang ruang lingkupnya lebih jauh dibandingkan dengan LAN. Model jaringan seperti ini umumnya digunakan di perkotaan, seperti pada penerapan smart city di kota besar.

3. Wide Area Network (WAN)

Merupakan jaringan yang ruang lingkupnya mencakup daerah geografis seperti negara atau benua.

\subsection{Kriptografi}

Kriptografi adalah suatu bidang ilmu/seni yang mempelajari tentang mekanisme dalam menjaga kerahasiaan pesan (Nagar \& Alshamma, 2012). Dalam menjaga kerahasiaan pesan, pesan tersebut akan diubah menjadi data acak atau data yang disandi sehingga hanya pengguna yang memiliki akses terhadap pesan tersebut yang dapat membaca isi pesan (Munir, 2008).

\subsection{Algoritma RSA}

Algoritma RSA ditemukan oleh peneliti dari MIT (Massachusetts Institute of Technology) yaitu Ronald L. (R)ivest, Adi (S)hamir, Leonard (A)dleman. Sebagai algoritma kunci publik, RSA mempunyai dua kunci, yaitu kunci publik dan kunci pribadi (Preetha \& Nithya, 2013). Kunci publik boleh diketahui oleh siapa saja dan digunakan untuk proses enkripsi. Sedangkan kunci pribadi hanya pihak-pihak tertentu saja yang boleh mengetahuinya dan digunakan untuk proses dekripsi. Keamanan sandi RSA (Rivest-Shamir-Adleman) terletak pada sulitnya memfaktorkan bilangan yang besar. Sampai saat ini RSA (Rivest-Shamir-Adleman) masih handal dan digunakan secara luas (Jaiswal, 2014). 


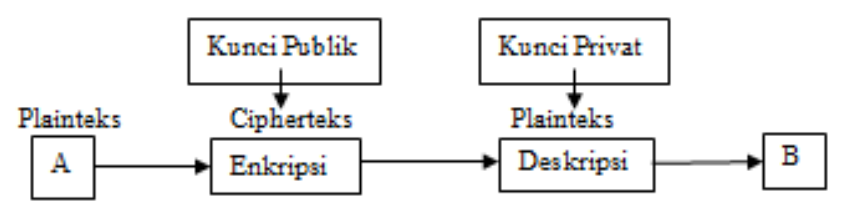

Gambar 1 Skema Algoritma Kunci Publik

Besaran-besaran yang digunakan pada algoritma RSA (Rivest-Shamir-Adleman) antara lain:

1. $\mathrm{p}$ dan $\mathrm{q}$ bilangan prima

(rahasia)

2. $\mathrm{n}=\mathrm{p} . \mathrm{q}$

3. $\mathrm{db}(\mathrm{n})=(\mathrm{p}-1)(\mathrm{q}-1)$

4. e (kunci enkripsi)

5. d (kunci deskripsi)

6. m (plainteks)

7. c (cipherteks) (tidak rahasia)

(rahasia)

(tidak rahasia)

(rahasia)

(rahasia)

(tidak rahasia)

Secara garis besar, proses kriptografi pada algoritma RSA (Rivest-Shamir-Adleman) terdiri dari 3 tahapan yaitu (Padmavathi \& Kumari, 2013) :

1. Pembangkitan Kunci

Untuk membangkitkan kedua kunci, dipilih dua buah bilangan prima yang besar, misalkan $\mathrm{p}$ dan $\mathrm{q}$. Untuk mendapatkan keamanan yang maksimum, dipilih dua bilangan $\mathrm{p}$ dan $\mathrm{q}$ yang besar. Kemudian dihitung:

Kemudian dihitung:

$$
\mathrm{n}=\mathrm{p} * \mathrm{q}
$$

$$
\Phi(\mathrm{n})=(\mathrm{p}-1)(\mathrm{q}-1)
$$

Lalu dipilih kunci enkripsi secara acak, sedemikian sehingga e dan (p-1) (q-1) relatif prima. Artinya e dan $\varphi$ tidak memiliki faktor persekutuan bersama. Kemudian dengan algoritma Euclidean yang diperluas lalu dihitung kunci dekripsi d, sedemikian sehingga:

$$
\text { ed }=1 \bmod (\mathrm{p}-1)(\mathrm{q}-1)
$$

atau

$$
\text { ed }-1=\mathrm{k}(\mathrm{p}-1)(\mathrm{q}-1)
$$

di mana $\mathrm{k}$ merupakan konstanta integer. Perhatikan bahwa d dan $\mathrm{n}$ juga relatif prima. Bilangan e dan $\mathrm{n}$ merupakan kunci publik, sedangkan d kunci pribadi. Dua bilangan prima $\mathrm{p}$ dan $\mathrm{q}$ tidak diperlukan lagi. Namun $\mathrm{p}$ dan $\mathrm{q}$ kadang diperlukan untuk mempercepat perhitungan dekripsi.

2. Proses Enkripsi

Untuk mengenkripsi pesan $\mathrm{m}$, terlebih dahulu pesan dibagi kedalam blok-blok numerik yang lebih kecil dari $\mathrm{n}$ (dengan data biner, dipilih pangkat terbesar dari 2 yang kurang dari $n$ ). Jadi jika $\mathrm{p}$ dan $\mathrm{q}$ bilangan prima 100 digit, maka $\mathrm{n}$ akan memiliki sekitar 200 buah digit dari setiap blok pesan m, seharusnya kurang dari 200 digit panjangnya. Pesan yang terenkripsi (c), akan tersusun dari blok-blok (c) yang hampir sama panjangnya. Rumus enkripsinya adalah:

dimana:

$$
\mathrm{c}=\mathrm{m}^{\mathrm{e}} \bmod \mathrm{n}
$$

$\mathrm{m}=$ pesan asli

$\mathrm{e}=$ proses enkripsi

$\mathrm{c}=$ pesan dalam bahasa sandi

$\mathrm{n}=$ modulus

\section{Proses Dekripsi}

Setelah menerima pesan yang sudah terenkripsi maka penerima pesan akan melakukan proses dekripsi pesan dengan cara:

$$
\mathrm{m}=\mathrm{c}^{\mathrm{d}} \bmod \mathrm{n}
$$

dimana:

$\mathrm{m}=$ pesan asli

$$
\begin{aligned}
& \mathrm{d}=\text { proses dekripsi } \\
& \mathrm{c}=\text { pesan dalam bahasa sandi } \\
& \mathrm{n}=\text { modulus }
\end{aligned}
$$

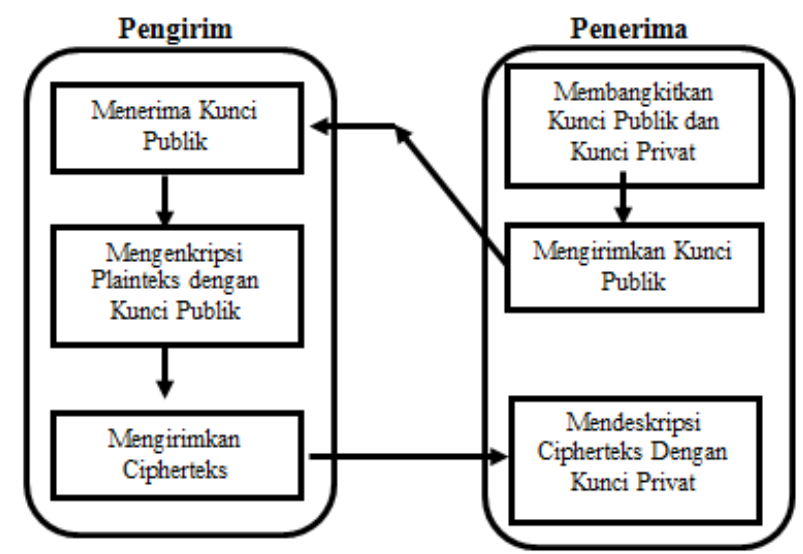

Gambar 2 Proses Algoritma RSA (Rivest-Shamir-Adleman)

Gambar 2 diatas menjelaskan tentang proses pembentukan algoritma RSA (Rivest-Shamir-Adleman). Algoritma RSA (Rivest-Shamir-Adleman) dijalankan dengan membangkitkan kunci publik dan kunci pribadi. Penerima kemudian mengirimkan kunci publik kepada pengirim untuk mengenkripsi pesan. Setelah pesan terenkripsi dalam bentuk ciphertext maka dapat dikirimkan kembali ke penerima. Setelah penerima mendapatkan pesan tersebut maka dapat di dekripsi dengan kunci pribadinya.

Contoh proses Algoritma RSA (Rivest-Shamir-Adleman) dapat dijalankan pada tahapan-tahapan yaitu sebagai berikut:

plaintext $=\mathrm{m}=$ CINTA MATI

$\mathrm{m}$ diubah ke dalam bentuk ASCII =

67737884653277658473

Pembentukan kunci :

1. Misalkan $\mathrm{p}=47$ dan $\mathrm{q}=71$ ( $\mathrm{p}$ dan $\mathrm{q}$ harus bilangan prima ) dimana $\mathrm{p}$ dan $\mathrm{q}$ dipilih secara acak.

2. Hitung: $\mathrm{n}=\mathrm{p} * \mathrm{q}=47 * 71=3337$

3. $\operatorname{Maka} \Phi(\mathrm{n})=(\mathrm{p}-1)(\mathrm{q}-1)=3220$

4. Pilih kunci publik $\mathrm{e}=79$ (relatif prima terhadap 3220 karena pembagi terbesar bersamanya adalah 1).

5. Didapat kunci pribadi sebagai berikut :

e.d $=1(\bmod \phi(\mathrm{n}))$

$\mathrm{d}=1(\bmod \phi(\mathrm{n}))=1019$

6. Maka kunci publik dan kunci pribadi adalah

Kunci publik $=(e, n)=(79,3337)$

Kunci pribadi $=(\mathrm{d}, \mathrm{n})=(1019,3337)$

Ubah Plainteks menjadi ciphertext dengan kunci publik:

$\mathrm{c}_{1}=\mathrm{m}_{1}{ }^{\mathrm{e}} \bmod \mathrm{n}=67779 \bmod 3337=231$

$\mathrm{c}_{2}=\mathrm{m}_{2}{ }^{\mathrm{e}} \bmod \mathrm{n}=37879 \bmod 3337=3092$

$\mathrm{c}_{3}=\mathrm{m}_{3}{ }^{\mathrm{e}} \bmod \mathrm{n}=84679 \bmod 3337=470$

$\mathrm{c}_{4}=\mathrm{m}_{4}{ }^{\mathrm{e}} \bmod \mathrm{n}=53279 \bmod 3337=407$

$\mathrm{c}_{5}=\mathrm{m}_{5}{ }^{\mathrm{e}} \bmod \mathrm{n}=77679 \bmod 3337=14$

$\mathrm{c}_{6}=\mathrm{m}_{6}{ }^{\mathrm{e}} \bmod \mathrm{n}=58479 \bmod 3337=2842$

$\mathrm{c}_{7}=\mathrm{m}_{7}{ }^{\mathrm{e}} \bmod \mathrm{n}=07379 \bmod 3337=725$

Jadi ciphertext yang dihasilkan adalah 2313092470407142842725

Ubahlah ciphertext dengan menggunakan kunci pribadi:

$\mathrm{m}_{1}=\mathrm{c}_{1}{ }^{\mathrm{d}} \bmod \mathrm{n}=2311019 \bmod 3337=677$

$\mathrm{m}_{2}=\mathrm{c}_{2}{ }^{\mathrm{d}} \bmod \mathrm{n}=30921019 \bmod 3337=378$

$\mathrm{m}_{3}=\mathrm{c}_{3}{ }^{\mathrm{d}} \bmod \mathrm{n}=4701019 \bmod 3337=846$

$\mathrm{m}_{4}=\mathrm{c}_{4}{ }^{\mathrm{d}} \bmod \mathrm{n}=4071019 \bmod 3337=532$

$\mathrm{m}_{5}=\mathrm{c}_{5}{ }^{\mathrm{d}} \bmod \mathrm{n}=141019 \bmod 3337=776$

$\mathrm{m}_{6}=\mathrm{c}_{6}{ }^{\mathrm{d}} \bmod \mathrm{n}=28421019 \bmod 3337=584$

$\mathrm{m}_{7}=\mathrm{c}_{7}{ }^{\mathrm{d}} \bmod \mathrm{n}=28421019 \bmod 3337=73$ 


\section{METODE PENELITIAN}

\subsection{Gambaran Sistem}

Gambaran sistem merupakan gambaran lengkap tentang sistem yang akan dibangun. Sistem menggunakan 1 admin dan 2 client yang dibangun dalam jaringan localhost dan kemudian akan diberikan sistem keamanan dengan menerapkan algoritma RSA dalam proses enkripsi dan deskripsi pesan.

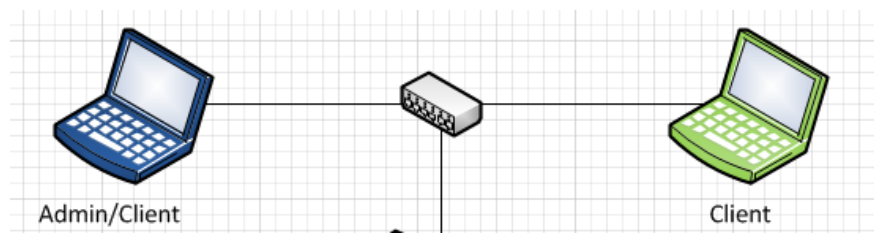

Gambar 3 Jaringan lokal

\subsection{Flowchart}

Flowchart pada Algoritma RSA (Rivest-Shamir-Adleman) disusun sesuai tahapan proses yaitu terdiri dari Setup Key, Proses Enkripsi, dan Proses Dekripsi.

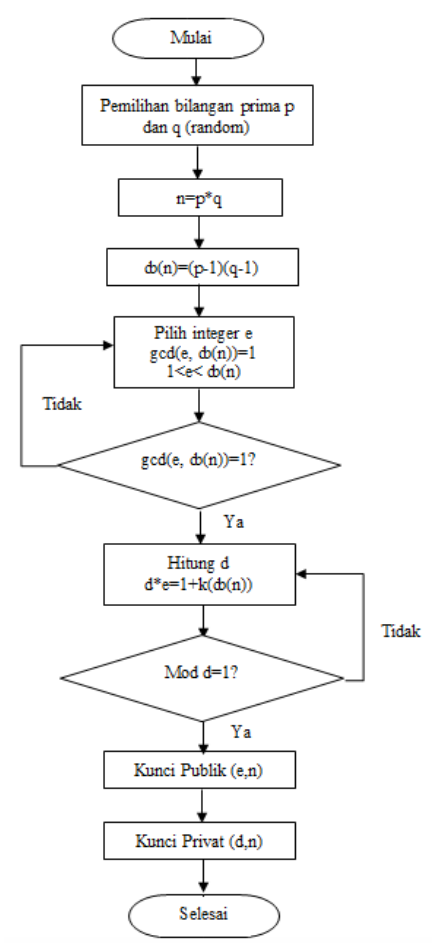

Gambar 4 Flowchart Setup Key

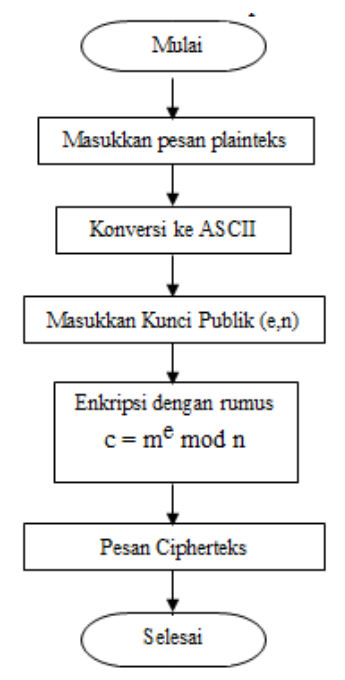

Gambar 5 Flowchart Proses Enkripsi

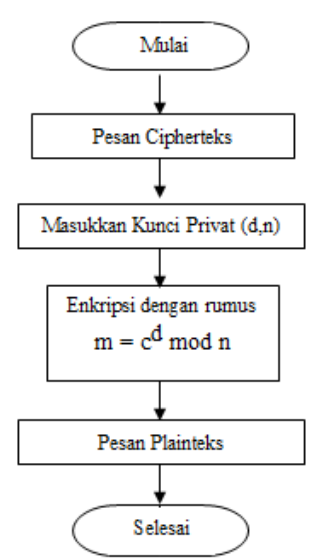

Gambar 6 Flowchart Proses Deskripsi

\section{HASIL DAN PEMBAHASAN}

Algoritma RSA diterapkan pada perangkat lunak yang dapat melakukan proses enkripsi dan dekripsi pesan sehingga dapat mengamankan data "chat" antar pengguna.

Dalam proses pengiriman pesan dimasukkan dalam database mysql yang ditampilkan dalam ERD (Entity Relationship Diagram) di bawah ini.

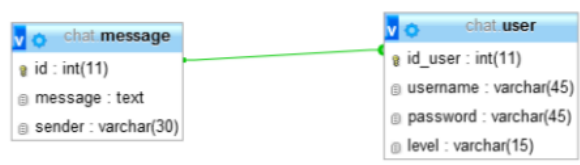

\section{Gambar 7 ERD Pengiriman Pesan}

Perangkat lunak yang dihasilkan terdiri dari 5 halaman yaitu halaman utama, halaman admin, halaman penerima, halaman pengirim, dan halaman penyerang yang masing - masing halaman dapat dilihat pada gambar di bawah ini. 


\subsection{Halaman Utama}

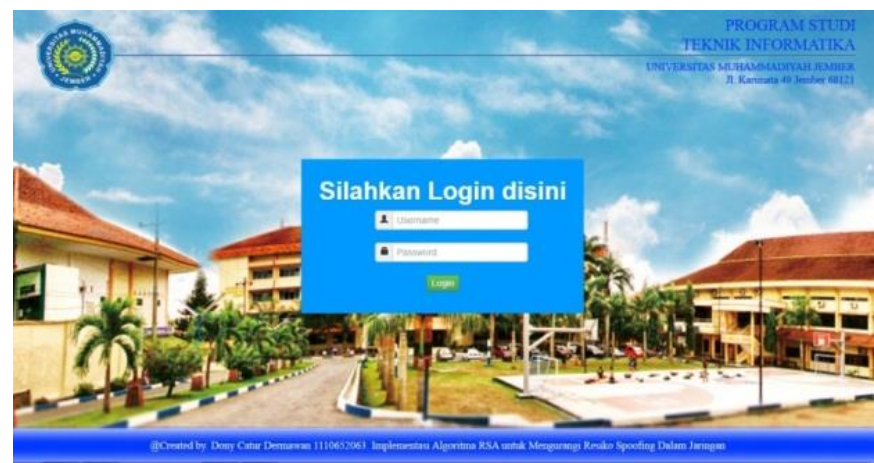

Gambar 8 Halaman Utama

Gambar 8 halaman utama yang terdapat form untuk login dengan mempunyai 3 hak akses pengguna yaitu admin, pengirim, dan penerima. Bisa juga ke halaman penerima maka username yang dimasukkan adalah galih maka akan masuk ke halaman penerima.php. Jika ingin masuk ke halaman pengirim yaitu pengirim.php maka username-nya ratna.

\subsection{Halaman Admin}

Halaman admin adalah halaman yang digunakan untuk melakukan semua proses dalam aplikasi ini. Termasuk untuk mencoba jalannya aplikasi yang akan disimulasikan. Halaman ini dapat dilihat pada gambar 9

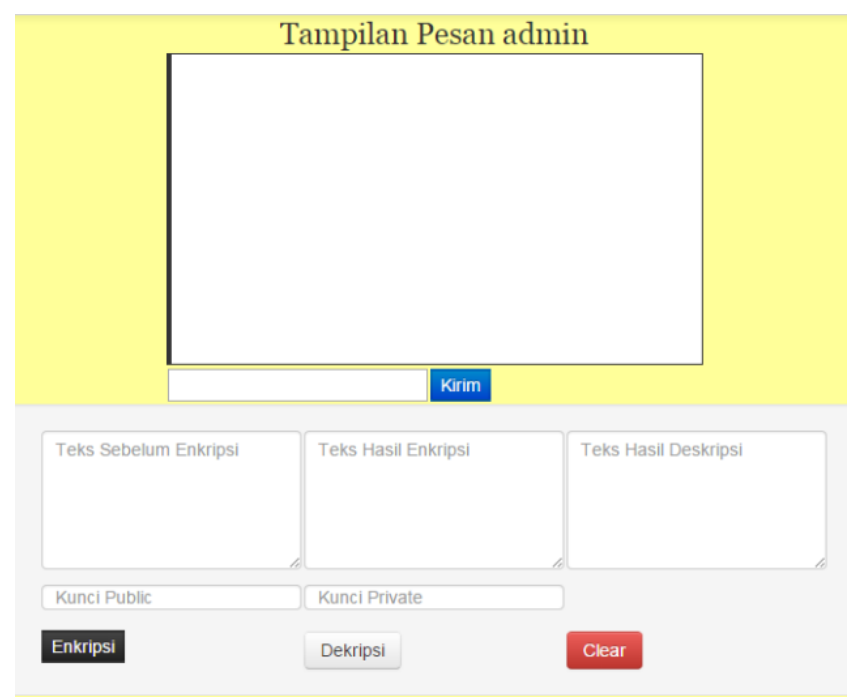

Gambar 9 Halaman Admin

\subsection{Halaman Penerima}

Pada halaman ini terdapat tampilan pesan, dan hasil pesan yang diterima yang akan di dekripsi menjadi pesan asli. Penerima juga bisa mengirimkan pesan asli sehingga dapat diketahui oleh pengirim dan penyerang. Halaman penerima ini juga dilengkapi waktu eksekusi untuk mendeskripsikan karakter. Halaman ini dapat dilihat pada gambar 10
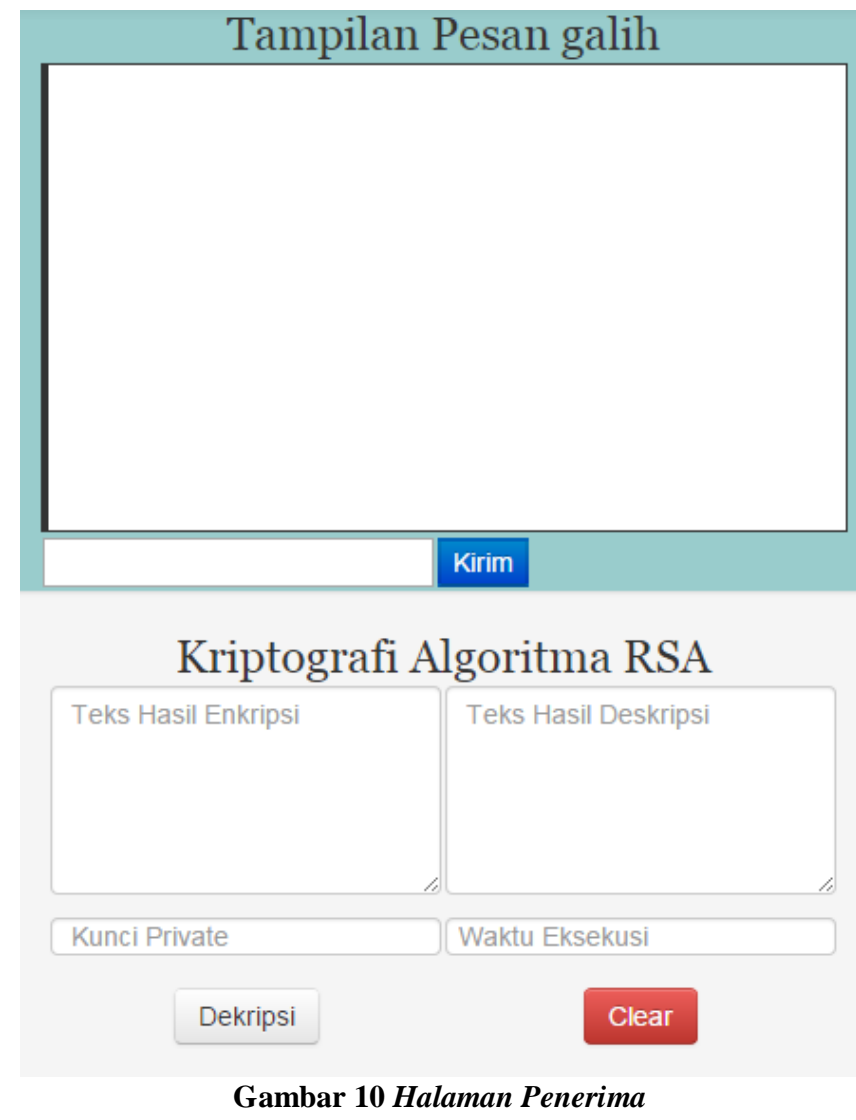

\subsection{Halaman Pengirim}

Halaman ini dapat mengirimkan pesan asli dan pesan yang telah di enkripsi atau ciphertext. Pengirim merupakan pengirim pesan yang ditujukan pada penerima, oleh karena itu pengirim hanya bisa mengenkripsi data menjadi ciphertext dan hanya penerima yang akan mendeskripsikannya menjadi pesan asli kembali. Halaman ini dapat dilihat pada gambar 11

\section{Tampilan Pesan ratna}

\section{Kriptografi Algoritma RSA}

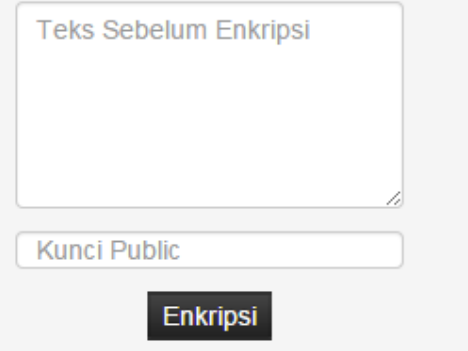

Gambar 11 Halaman Pengirim 


\subsection{Pengiriman Pesan Terenkripsi}

Setelah melakukan proses pengiriman pesan yang dapat disadap oleh attacker kemudian dibuat pengiriman pesan yang terenkripsi. Simulasi pesan ini akan dijalankan pada proses enkripsi pesan yang akan dikirimkan kemudian saat pesan diterima pihak dapat mendeskripsikan pesan tersebut sehingga pesan yang dijalankan terjamin keasliannya. Dalam aplikasi ini juga diasumsikan bahwa attacker juga dapat menyerang aplikasi tetapi hal tersebut dapat diatasi setelah proses dekripsi sehingga pesan yang dikirimkan attacker tidak akan terbaca. Pada gambar 12 di bawah ini terjadi proses enkripsi pesan oleh ratna kemudian dikirimkan kepada galih. Pesan yang terenkripsi akan berupa angka yang telah dibentuk menggunakan algoritma RSA (Rivest-ShamirAdleman).

\section{Tampilan Pesan ratna}

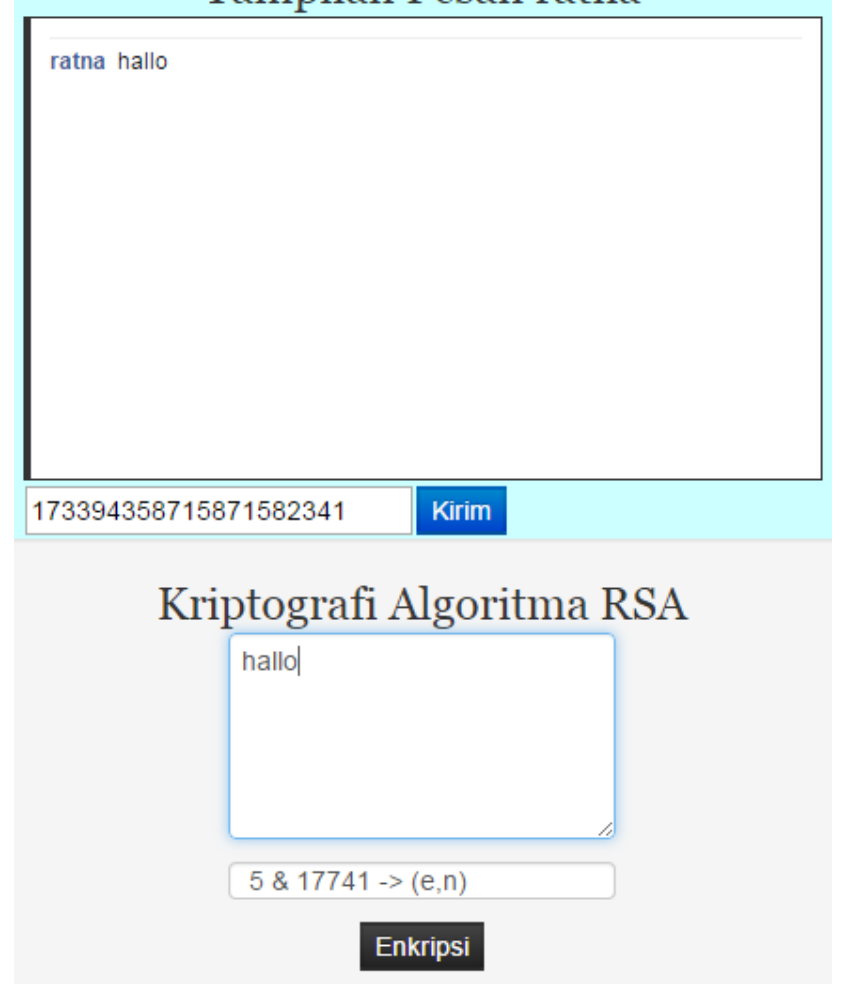

Gambar 12 Pengiriman Pesan Terenkripsi

Pesan yang dikirimkan melalui jaringan sudah dalam bentuk terenkripsi. Pada gambar 13 ditampilkan bahwa pesan sudah terkirim dalam bentuk enkripsi. Setelah itu galih dapat mendeskripsikan dengan kunci pribadinya.

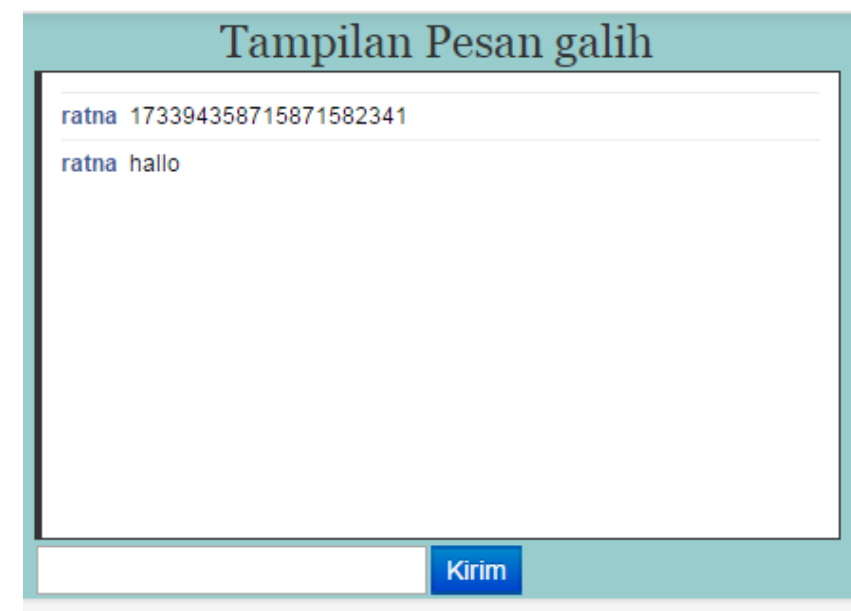

Kriptografi Algoritma RSA

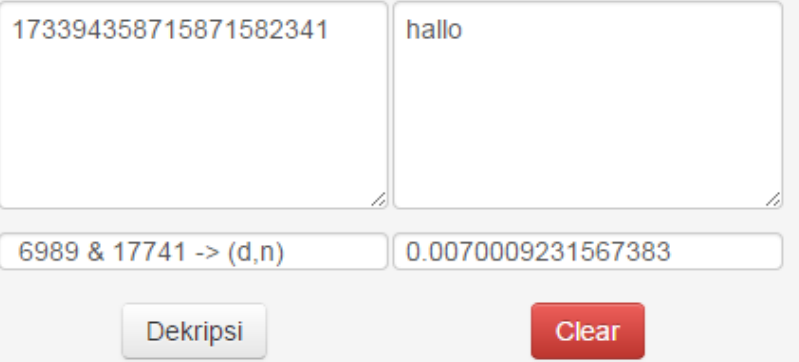

Gambar 13 Mendeskripsikan Pesan Yang Terkirim

Gambar 13 menunjukkan pesan yang terenkripsi dapat dideskripsikan dengan kunci pribadi sehingga pesan ciphertext dapat didefinisikan dan pesan asli tidak dapat. Jika pesan itu dienkripsi dengan kriptografi algoritma RSA (Rivest-Shamir-Adleman) maka pesan dapat di dekripsi.

Pada saat pengirimanan pesan ada proses verifikasi pesan ciphertext dan pesan asli sehingga pesan yang dikirimkan kepada galih benar-benar asli dari ratna. Saat attacker menyerang dengan data asli pada pesan galih maka hal tersebut tidak dapat didekripsi.

\section{KESIMPULAN DAN SARAN}

\subsection{Kesimpulan}

1. Sistem keamanan membantu mengamankan jaringan tanpa menghalangi penggunaannya dan menempatkan antisipasi ketika jaringan berhasil ditembus. Selain itu, bahwa ternyata pada proses spoofing yaitu man the middle attack sangat mungkin untuk menjebol informasi pesan yang dikirimkan lewat jaringan.

2. Sistem enkripsi kunci publik-pribadi, yang memegang peranan dalam menjebol kunci pribadi adalah kesulitan mencari faktor prima bilangan yang besar. Kunci publik dari RSA (Rivest-Shamir-Adleman) pada tahap uji coba belum dapat ditembus menggunakan teknik brute force attack sehingga pesan tetap aman.

3. Pesan yang dikirimkan melalui jaringan lokal sulit didekripsi jika tidak mengetahui kunci pribadi. Pada proses enkripsi meskipun kunci publik sudah diketahui orang lain tetapi tetap pihak attacker tidak bisa mengenkripsi pesan aslinya. 


\subsection{Saran}

Berdasarkan penelitian yang sudah dikerjakan, terdapat saran untuk melengkapi kekurangan penelitian.

1. Perlu diterapkan protokol ssl untuk memperkuat keamanan di level layer 3 dan 4 sehingga proses pengiriman data dapat terenkripsi.

2. Perlu dilakukan modifikasi teknik enkripsi dengan melakukan improvisasi random karakter sehingga tidak murni dalam menerapkan algoritma RSA karena beberapa ujicoba sudah hampir mendapatkan kunci pribadi.

\section{DAFTAR PUSTAKA}

Cahyanto, T. A. (2011). Analisis deteksi penyusupan pada jaringan komputer menggunakan snort (studi kasus pada Dinas Pariwisata Propinsi Daerah Istimewa Yogyakarta). Yogyakarta. Retrieved from http://search.jogjalib.com/Record/uinsukalib073461\#details

Cahyanto, T. A. (2018). Implementasi Smart Router Berbasis OpenWRT Sebagai Media Untuk File Sharing dan Chatting Pada Laboratorium Terpadu Unmuh Jember. https://doi.org/10.17605/OSF.IO/P6BWS

Cahyanto, T. A., Oktavianto, H., \& Royan, A. W. (2013). Analisis dan Implementasi Honeypot Menggunakan Dionaea Sebagai Penunjang Keamanan Jaringan. JUSTINDO (Jurnal Sistem Dan Teknologi Informasi Indonesia), 1(2), 86-92.

Cahyanto, T. A., \& Prayudi, Y. (2014). Investigasi Forensika Pada Log Web Server untuk Menemukan Bukti Digital Terkait dengan Serangan Menggunakan Metode Hidden Markov Models. SNATi, 15-19.

Jaiswal, R. J. (2014). Reformed RSA algorithm based on Prime Number. International Journal of Computer Applications, 975-8887.

Munir, I. R. (2008). Pengantar Kriptografi, 16. Retrieved from

http://informatika.stei.itb.ac.id/ rinaldi.munir/Kriptogra fi/Pengantar Kriptografi.pdf

Munir, I. R. (2010). Algoritma RSA dan ElGamal, 13. Retrieved from http://informatika.stei.itb.ac.id/ rinaldi.munir/Kriptogra fi/Algoritma RSA.pdf

Nagar, S. A., \& Alshamma, S. (2012). High speed implementation of RSA algorithm with modified keys exchange. In 2012 6th International Conference on Sciences of Electronics, Technologies of Information and Telecommunications, SETIT 2012 (pp. 639-642). https://doi.org/10.1109/SETIT.2012.6481987

Padmavathi, B., \& Kumari, S. R. (2013). A Survey on Performance Analysis of DES, AES and RSA Algorithm along with LSB Substitution Technique. International Journal of Science and Research (IJSR), 2(4), 170-174. Retrieved from https://www.ijsr.net/archive/v2i4/IJSRON120134.pdf

Preetha, M., \& Nithya, M. (2013). A STUDY AND PERFORMANCE ANALYSIS OF RSA ALGORITHM. IJCSMC, 2(6), 126-139. Retrieved from

http://www.ijcsmc.com/docs/papers/June2013/V2I6201 330.pdf

Vikas, A., Agrawal, S., \& Deshmukh, R. (2014). Analysis and Review of Encryption and Decryption for Secure Communication. International Journal of Scientific
Engineering and Research (IJSER), 2(2), 2-4. Retrieved from http://www.ijser.in/archives/v2i2/SjIwMTMxMTU=.pd $\mathrm{f}$

Xin Zhou, Xiaofei Tang, Zhou, X., \& Tang, X. (2011). Research and Implementation of RSA Algorithm for Encryption and Decryption. Proceedings of 2011 6th International Forum on Strategic Technology, 11181121. https://doi.org/10.1109/IFOST.2011.6021216 